\title{
POWSZECHNY I BEZWARUNKOWY DOCHÓD PODSTAWOWY JAKO REALNY CZYNNIK ODBUDOWY RÓWNOWAGI NA RYNKACH PRACY
}

https://doi.org/10.33141/po.2018.09.02

\section{Adam Peszko}

\section{Wp}

- stał w innych warunkach ustrojowych 44 lata temu i wymaga nowelizacji. Dlatego 18 września 2016 roku prezes Rady Ministrów powołał na 18-miesięczną kadencję nową Komisję Kodyfikacyjną Prawa Pracy. Komisja liczyła 14 osób, sześciu członków komisji zostało wskazanych przez ministra rodziny, pracy i polityki społecznej, trzech reprezentowało organizacje związkowe, a czterech organizacje pracodawców. Jej celem było wypracowanie projektów indywidualnego i zbiorowego prawa pracy. We wstępnej fazie prac Komisja dokonała przeglądu prac swojej poprzedniczki, działającej w latach 2002-2006, uznając, że przygotowane przez zespoły niezależnych ekspertów projekty nie tworzą spójnego systemu prawa pracy i punktem wyjściowym będą obowiązujące dziś przepisy (Laska, 2018).

W połowie marca br. Komisja przyjęła projekty nowego „Kodeksu Pracy” i „Kodeksu zbiorowego prawa pracy”. Oba dokumenty przed przekazaniem do Sejmu mają być przedmiotem dalszych dyskusji w Radzie Dialogu Społecznego. Doniesienia prasowe $\mathrm{z}$ dotychczasowych konsultacji są bardzo sceptyczne. Dominuje przekonanie, że z nowego „Kodeksu Pracy” nie są zadowoleni ani pracodawcy, ani związkowcy. Sami członkowie komisji, tłumacząc zawiłości nowych przepisów, powtarzają, że „intencje autorów były inne” (Rozwadowska, 2018). Tytuły niektórych komentarzy stwierdzają wprost: „Fiasko nowego Kodeksu Pracy?”, a z ich treści można się dowiedzieć, że zarówno obowiązujący „Kodeks Pracy”, jak i nowe projekty w wielu aspektach nie wychodzą naprzeciw wyzwaniom współczesności, a trwająca dyskusja nad jego doskonaleniem nie może prowadzić do dalszego pogarszania sytuacji pracowników (Radzikowski, 2018). Wielki niepokój wyraża też autor innej publikacji zaczynającej się od słów: „Umarł projekt nowego Kodeksu Pracy. Wyzionął ducha, bo okazało się, że w obecnej konfiguracji politycznej nie ma nikogo, kto by chciał o inne podejście do prawa pracy choć trochę powalczyć. Szkoda” (Woś, 2018). Podstawowym źródłem krytyki nowego projektu jest to, że Komisja Kodyfikacyjna chciała zadowolić obie strony, zarówno pracodawców, jak i pracowników. Dla przykładu: wprowadzono, zgodnie z postulatem związkowców, domniemanie istnienia stosunku pracy i dla równowagi przyjęto też postulat pracodawców, dotyczący zastosowania nowych rodzajów umów o pracę, które przyczyniłyby
Przegląd Organizacji, Nr 9 (944), 2018, ss. 15-20 www.przegladorganizacji.pl @Towarzystwo Naukowe Organizacji i Kierownictwa (TNOiK)

się do dalszego uelastycznienia rynku pracy. W wyniku nowo powstałe projekty kodeksu są pełne sprzeczności i umożliwiają różnorodne interpretacje. Szanse, że wejdą w życie, są nikłe.

Okazuje się, że bez porównania łatwiej było wprowadzić kompleksowe regulacje ustrojowe dotyczące funkcjonowania rynków towarów i usług oraz finansów niż kodyfikacje regulujące rynek pracy. Wynika to z dynamicznych zmian strukturalnych rynków pracy, wywoływanych postępującym procesem globalizacji gospodarki światowej oraz wpływem nowych technologii i cyfryzacji na spadek zatrudnienia w procesach produkcyjnych. Celowe wydaje się więc podjęcie szerszej dyskusji nad systemowymi bardziej radykalnymi rozwiązaniami problemów rynku pracy w naszym kraju. W wielu bogatych krajach zachodniej Europy toczą się już od dawna dyskusje nad wykorzystaniem zupełnie nowej instytucji: powszechnego, bezwarunkowego dochodu podstawowego w wersji proponowanej przez profesora Uniwersytetu Londyńskiego Guya Standinga. Trzeba przyznać, że jest ona niezwykle radykalna i z tego względu wzbudza wiele kontrowersji, zwłaszcza wśród pracodawców i polityków. Ale problem rozwoju gospodarczego $\mathrm{z}$ zachowaniem społecznie pożądanego stanu równowagi, pomiędzy dochodami z pracy najemnej a dochodami $\mathrm{z}$ kapitału, nie jest nowy w światowej literaturze ekonomicznej.

Podejmuje go między innymi w swej fundamentalnej pracy „Zarządząnie strategiczne” Harry I. Ansoff (1985, s. 29-38), traktujący przedsiębiorstwo jako „organizację służącą otoczeniu” (OSO). Bogate wnioski wyciągnąć można $\mathrm{z}$ analizy podejścia do organizacji pracowniczych od strony kosztów transakcyjnych w nowej ekonomii instytucjonalnej, którą przedstawia laureat ekonomicznego Nobla z roku 2009 Oliver E. Williamson (1998, s. 245-277).

Najbardziej alarmujące sygnały, dotyczące zdecydowanego załamania równowagi pomiędzy dochodami z pracy a rentą kapitałową (na niekorzyść dochodów z pracy), wynikają jednak z prac ekonomistów zajmujących się badaniem nierówności dochodowych i majątkowych $\mathrm{w}$ gospodarce zglobalizowanej. Z pozycji dostępnych w polskim przekładzie warto wymienić w pierwszej kolejności książkę zatytułowaną „Kapitał XXI wieku”, którego autorem jest Thomas Piketty, i drugą pt. „Cena nierówności. W jaki sposób dzisiejsze podziały społeczne zagrażają naszej przyszłości?” autorstwa Noblisty 2001 r. Josepha 
E. Stiglitza. Lektura tych dwu pozycji pozwala zrozumieć praźródła radykalizmu G. Standinga w jego koncepcji bezwarunkowego, powszechnego dochodu podstawowego.

Dopuszczalna objętość niniejszego artykułu nie pozwala autorowi nawet na hasłową prezentację wniosków, które wyprowadzają T. Piketty i J.E. Stiglitz. Odsyłając więc czytelnika do powołanych wyżej źródeł, uwaga zostanie skoncentrowana zatem na samej koncepcji bezwarunkowego dochodu podstawowego.

Głównym celem niniejszego artykułu jest prezentacja istoty instytucji bezwarunkowego dochodu podstawowego w wersji proponowanej przez Guya Standinga z wstępną próbą oceny przydatności tej koncepcji do przywracania równowagi pomiędzy pracą a kapitałem na rynkach pracy w gospodarce globalnej.

\section{Powszechny i bezwarunkowy dochód podstawowy w koncepcji Guya Standinga}

W przedmowie do „Karty prekariatu” (Standing, 2015) autor stwierdza, że przyczyną napisania tej książki było wysłuchanie osobistych opowieści „przedstawicieli prekariatu” (Standing 2015, s. 1), bo jego zdaniem wyraźnie kształtuje się nowa klasa społeczna, nazwana przez niego „prekariatem”. Komunikuje też, że książka: „Stanowi kulminację długiej podróży, która zaczęła się w jego wypadku w latach osiemdziesiątych od artykułów i wielu krajowych monografii na temat elastyczności rynku pracy najemnej w Wielkiej Brytanii, Szwecji, Finlandii, Holandii, Hiszpanii, Niemczech, Włoszech i Austrii. Niektóre z nich zostały napisane razem z lub przez moich kolegów i koleżanki z Międzynarodowej Organizacji Pracy lub szeroko rozumianej akademii. Stojąca za tymi tekstami teza sprowadza się do przekonania, że model neoliberalny wytworzy jeszcze więcej ekonomicznej niepewności i społecznych podziałów" (Standing, 2015, s. 2).

W ujęciu G. Standinga „prekariat” składa się z ludzi, żyjących z pracy na niepewnych stanowiskach, co przeplata się z okresami bezrobocia lub wycofywania się z siły roboczej. Prekariusze doświadczają stale niepewności życiowej w zakresie dostępu do mieszkalnictwa i publicznych zasobów. Ich udziałem jest ciągłe poczucie przejściowości. Charakterystyczne jest podkreślenie, iż podstawą jego książki ,jest twierdzenie, że prekariat to klasa w procesie tworzenia, która musi stać się klasą dla siebie w stopniu wystarczającym do tego, aby szukać dróg do samozniesienia. To właśnie czyni prekariat transformacyjnym w przeciwieństwie do innych istniejących klas, które chcą się jedynie umacniać w ramach własnej reprodukcji” (Standing, 2015, s. 3).

Szeroką charakterystykę prekariatu i mechanizmy wyłonienia się oraz ciągłego wzrostu liczebności tej klasy, w warunkach postępującej globalizacji gospodarki światowej, przedstawiono $\mathrm{w}$ ubiegłorocznym artykule w Przeglądzie Organizacji pt.: „Społeczne aspekty wzrostu nierówności w liberalnej gospodarce globalnej” (Peszko, 2017, s. 50-56). Odsyłając czytelnika do treści tego artykułu, trzeba wyraźnie podkreślić, że siłą napędową mechanizmu wzrostu liczebności prekariatu jest rosnąca nierównowaga pomiędzy kapitałem a pracą na globalnym rynku pracy. Potwierdzają to jednoznacznie zestawienia statystyczne udziału wynagrodzeń w PKB i udziału dochodów z pracy w stosunku do wartości wytworzonej produkcji. W Stanach Zjednoczonych Ameryki Północnej jeszcze przed krachem 2008-2009 udział wynagrodzeń w dochodzie narodowym spadł z szczytowych $53 \%$ w roku 1970, do 45\%, a do końca 2012 roku obniżył się dalej do 43,5\%. Trend spadkowy udziału wynagrodzeń w PKB ma charakter globalny i np.: w Chinach od połowy lat 90. do połowy pierwszej dekady XXI wieku udział dochodów $\mathrm{z}$ pracy w stosunku do wartości wytworzonej produkcji spadł z 48 do $42 \%$, a w Indiach z 37 do $22 \%$. Pozytywna zależność między wydajnością a płacami zatrzymała się już w latach osiemdziesiątych, a gwałtowna przepaść nastąpiła po roku 2000. W ten sposób złamano niepisaną społeczną umowę ery powojennej, według której - realne płace miały rosnać równolegle do wzrostu wydajności. W zglobalizowanej gospodarce kapitał doskonale mobilny w skali światowej nie potrzebował już tego kompromisu (Standing, 2015, s. 44). Warto dodać, że mobilność globalna kapitału nie podlega żadnej kontroli, a zyski uzyskane na operacjach finansowych niezgodne $\mathrm{z}$ prawem można bez problemu ukrywać w „rajach podatkowych”.

Należy przy tym zauważyć, że G. Standing, zafascynowany gwałtownym wzrostem mobilności kapitału w skali globalnej, nie docenia w dostatecznym stopniu wpływu nowych technologii i cyfryzacji na spadek zatrudnienia $\mathrm{w}$ procesach produkcji w krajach wysokorozwiniętych. To przemawia dodatkowo za jego tezą docelową o konieczności wprowadzenia powszechnego i bezwarunkowego dochodu podstawowego.

Postulat G. Standinga (2015, s. 322) jest jednoznaczny: „Rządy powinny zmierzać do ustanowienia dochodu podstawowego jako prawa obywatelskiego. W globalnej gospodarce rynkowej niepewność i nierówności jedynie się pogłębią, jeśli nie wprowadzimy nowych rozwiązań, niezbędne jest gruntowne przebudowanie systemu opieki społecznej".

Tradycyjna gospodarka kapitalistyczna charakteryzowała się wyraźnym podziałem na płace i zyski z kapitału, a rządy narodowe pośredniczyły w walce między siłą roboczą i właścicielami kapitału, stosując różnorodne metody regulacji, podatki i subwencje. W warunkach globalizacji płace ustąpiły pola, a dochody $\mathrm{z}$ wynajmu kapitału finansowego gwałtownie rosną. Trzeba zmienić naszą wyobraźnię ekonomiczną i przyjąć, że wprowadzenie prawa o wypłacaniu gwarantowanego dochodu podstawowego (czyli miesięcznej kwoty wystarczającej na zapewnienie każdemu legalnemu mieszkańcowi podstawowego bezpieczeństwa) jest nieodzowne. Bez tego prawa niepewność, zadłużenie i nierówności będą dalej rosnąć.

Terminu "podstawowy" używa G. Standing w podwójnym znaczeniu. $\mathrm{Z}$ jednej strony kwota tego dochodu powinna być podstawowa, tj. wystarczająca do przeżycia, niezapewniająca jednak pełnego bezpieczeństwa, bo to skłaniałoby już do braku ostrożności. Z drugiej strony "podstawowy” oznacza, że bez niego inne prawa, np. do edukacji czy pracy, są niemożliwe do realizacji. Kwota 
dochodu podstawowego winna wystarczać na pokrycie podstawowych potrzeb materialnych, ułatwiając dążenia do osiągania innych życiowych celów, z tego powodu jej poziom winien docelowo być powiązany $\mathrm{z}$ medianą dochodów. Autor koncepcji nie traktuje tej ostatniej propozycji kategorycznie, gdyż zdaje sobie sprawę, że rzeczywista wysokość dochodu podstawowego wypłacanego przez rząd musi być oparta o realne możliwości budżetowe gospodarki narodowej.

Powszechny dochód podstawowy winien być wypłacany indywidualnie bez wiązania go z pojęciami gospodarstwa domowego czy rodziny, bo wiązałoby się to z arbitralnymi, niepotrzebnie wścibskimi i kosztownymi mechanizmami administracyjnymi. Wypłaty winny być realizowane w formie pieniężnej, regularnie, w sposób przewidywalny i bezwarunkowy, czyli bez reguł dotyczących zachowania. Jego wypłata winna więc być prawem obywatelskim, które ograniczać może tylko jakaś pragmatyczna zasada w odniesieniu do migrantów. Wypłaty dochodu podstawowego muszą mieć charakter powszechny, a odzyskiwanie go od otrzymujących go osób zamożniejszych winny się odbywać za pomocą podatków.

Kluczowe jest to, żeby wypłaty powszechnego dochodu podstawowego rosły wraz $\mathrm{z}$ rozwojem gospodarczym. Zaczynać można od stopniowego przekształcania obecnych świadczeń społecznych, zmieniając istniejące selektywne transfery w granty bezwarunkowe, a następnie rozszerzać je na pozostałe grupy (Standing, 2015, s. 124).

Dochód podstawowy to jedyne rozwiązanie, które poprawia ekonomiczne i społeczne bezpieczeństwo najbardziej pozbawionych ochrony grup społecznych, nie nakładając dodatkowej kontroli nad żadną grupą społeczną. Zwiększa więc on wolność osobistą i ma zdecydowaną przewagę nad tradycyjną dobroczynnością, bo usuwa swobodę decydowania przez biurokrację, komu należy się wsparcie oraz czyje zachowanie domaga się współczucia, a czyje sankcji.

Najbardziej przekonujących argumentów ekonomicznych za wprowadzeniem powszechnego dochodu podstawowego dostarcza sam proces globalizacji gospodarki, w którym uelastycznianiu stosunków zatrudnienia towarzyszy rozmontowywanie instytucji i mechanizmów solidarności społecznej i ochrony socjalnej. Nie ma jednak od tego procesu odwrotu. Systemy ubezpieczenia społecznego funkcjonowały, gdy większość mogła wnosić swój wkład w fundusz ubezpieczeniowy, a ludzi z grubsza dotyczyło równe prawdopodobieństwo nieszczęścia. Warunki te zostały zniszczone przez postępujące zmiany gospodarcze i polityczne. Indywidualizm i elastyczność uczyniły wyniki coraz bardziej nierównymi, a mobilność społeczna spadła. Udział płac w dochodzie narodowym wszystkich krajów ciągle maleje, osoby będące częścią siły roboczej i te, które znalazły się poza nią, nie są w stanie płacić regularnych i wystarczających składek. Podwyższanie niskich płac za pomocą ulg podatkowych jest kosztowne, zniekształcające rzeczywistość, nieefektywne, niesprawiedliwe i zmuszające do ciągłej administracyjnej selekcji ludzi na biednych i bogatych. Powszechny dochód podstawowy nie miałby tych negatywnych cech, byłby powszechny, pozwalałby wszystkim na pertraktacje i wolność wyboru.
Najistotniejsze wydaje się jednak to, że wprowadzenie powszechnego dochodu podstawowego powinno zapewnić bardziej efektywne i sprawiedliwsze funkcjonowanie rynków pracy, co zależy głównie od siły przetargowej właściciela kapitału pełniącego funkcję pracodawcy i słabego pracobiorcy. Przy wysokiej stopie bezrobocia i niepewnym wsparciu dochodowym pozycja pracowników jest beznadziejnie słaba. Pracodawcy mogą z łatwością uzyskiwać zysk, ustalając niskie wynagrodzenia, zamiast troszczyć się o to, czy siła robocza jest właściwie wykorzystywana. Bez powszechnego dochodu podstawowego pracownicy gotowi są podjąć się każdej pracy, aby tylko otrzymać pieniądze, jednocześnie rozglądając się za czymś innym. W tych warunkach efektywność alokacji pracowników jest niska, rotacja kadr wysoka, a negatywne reakcje w miejscu pracy częste.

Dochód podstawowy chroniłby przed niepewnością i szokami, dodawał ludziom odwagi i pewności siebie przy podejmowaniu ryzyka i decydowaniu się na działania potencjalnie poprawiające życie. G. Standing wyraźnie stwierdza: „Jeżeli wiesz, że nie wylądujesz na ulicy w razie porażki, jesteś bardziej skłonny do podjęcia ryzyka nabywania nowych umiejętności lub porzucenia pozbawionych perspektyw stanowisk, aby spróbować szczęścia jako niezależny rzemieślnik" (Standing, 2005, s. 339) oraz podkreśla: „Nie powinno się omawiać dochodu podstawowego bez rozważenia pożądanych cech całego systemu opieki społecznej, który byłby oparty na współczuciu, solidarności i empatii, a nie kontroli i karaniu ubogich. Należy rozumieć dochód podstawowy jako podstawę wielowarstwowego systemu dopasowanego do realiów XXI wieku" (Standing, 2015, s. 340).

\section{Możliwości osiągnięcia równowagi na rynkach pracy po wdrożeniu dochodu podstawowego}

D owszechny bezwarunkowy dochód podstawowy ma prekursorów, bo na świecie funkcjonują już podobne programy, jak na przykład amerykański program Alaska Permanent Fund (Stały Fundusz Alaski), który jest hybrydą dochodu podstawowego i dotacji kapitałowej, ponieważ wypłaca każdemu mieszkańcowi Alaski roczną dywidendę pochodzącą z Funduszu Stałego utworzonego w 1976 r. Wprowadzono go, by zachęcić do osiedlania się w surowym klimacie tego półwyspu i ma charakter powszechny, ale tylko dla mieszkańców określonych rejonów. G. Standinga najbardziej niepokoi jednak to, że politycy dotychczas na ogół boją się przyznawania wszystkim prawa do bezpieczeństwa ekonomicznego, a nawet tych, którzy wierzą, że jest to wskazane, paraliżuje strach przed napiętnowaniem przez moralistów za brak realizmu czy utopię.

Dla pokonywania tego strachu specjalnie powołano organizację Basic Income Earth Network (Światowa Sieć na rzecz Dochodu Podstawowego). Działa ona w wielu krajach i między innymi zbierała podpisy pod Europejską Inicjatywą Obywatelską wnioskującą do Komisji Europejskiej o przeprowadzenie badań nad możliwością wprowadzenia 
dochodu podstawowego i uruchomienia programów pilotażowych. W 2013 roku udało się zebrać pod tą petycją ponad 285 tys. podpisów, ale do uznania przez Komisję Europejską potrzebne jest zebranie w ciągu roku 1 miliona podpisów w siedmiu krajach unijnych (Standing, 2015, s. 344).

Najbardziej zaawansowana w działaniach praktycznych była Szwajcaria, w której przeprowadzono nawet referendum na temat wypłaty wszystkim obywatelom tego kraju dochodu podstawowego. Przyniosło one jednak wynik negatywny. Od stycznia 2017 roku prowadzono eksperyment w Finlandii, gdzie wypłacano co miesiąc wybranej grupie bezrobotnych 560 euro. Chodziło o sprawdzenie, czy taki zastrzyk finansowy rozleniwi pracownika czy przeciwnie - zmobilizuje do szukania wyżej płatnej pracy. Wyniki eksperymentu fińskiego miały być ogłoszone w 2019 roku, ale z niewiadomych dotychczas przyczyn eksperyment przerwano, zawieszając jego finansowanie na rok 2018. Prasa donosi też o podobnych eksperymentach w Holandii i Włoszech (Woś, 2017, s. 52).

Pilotażowe wprowadzenie bezwarunkowego dochodu podstawowego w Niemczech zaproponował prof. Thomas Strarubhaar, wykładający stosunki międzynarodowe na Uniwersytecie Hamburskim. Swą propozycję uzasadnia tym, że już dziś państwo niemieckie wydaje rocznie na cele socjalne (w tym dotacje do systemu emerytalnego) 900 mld euro, co starczyłoby na comiesięczne wypłaty dla 82 mln Niemców ponad 900 euro miesięcznie. Ponadto zauważa, że Niemcy wyraźnie odczuwają już na rynku pracy skutki cyfryzacji, automatyzacji, robotyzacji i ta tendencja będzie się $u$ nich pogłębiać szybciej niż w innych krajach, ze względu na wysoki poziom technologiczny przemysłu i innowacyjność całej gospodarki. Propozycja T. Straubhaara obejmuje całkowitą przebudowę systemu podatkowego oraz likwidację składek emerytalnych i rentowych, a emerytury i renty wypłacano by w dotychczasowej wysokości tylko w okresie przejściowym. Po okresie przejściowym pozostawałby tylko podatek dochodowy, pozbawiony jakichkolwiek wyjątków i płacony bezpośrednio u źródła od każdego pierwszego zarobionego euro. Zwolniony od tego podatku byłby wyłącznie bezwarunkowy dochód podstawowy, a wszystkie dochody z pracy, zyski kapitałowe, tantiemy, dywidendy i przychody z wynajmu lub dzierżawy objęte byłyby taką samą stawką podatkową (Kowanda, 2017, s. 36-38).

Równolegle do tych pozytywnych eksperymentów nie słabnie krytyka wprowadzania bezwarunkowego dochodu podstawowego, a z niektórymi krytykami polemizuje autor koncepcji. Na przykład na zarzut, że dochodu podstawowego nie da się sfinansować, odpowiada, iż kwestią istotną jest przesunięcie środków na dochód podstawowy z subwencji, ulg podatkowych oraz świadczeń socjalnych zależnych od progów dochodowości (Standing, 2015, s. 328). Potwierdzałaby to przytoczona wyżej opinia, że w Niemczech już obecnie można by wprowadzić dochód podstawowy w wysokości 900 euro miesięcznie bez zwiększania wydatków budżetu.

Najczęściej powtarzany zarzut to twierdzenie, że dochód wypłacany bezwarunkowo, bez względu na status na rynku pracy, zmniejszy podaż na rynku pracy i skłoni do lenistwa. Autor ripostuje, iż badania psychologiczne potwierdzają, że znaczna większość ludzi nie zadowoli się bynajmniej środkami z dochodu podstawowego. Prawdziwymi zachętami do niepodejmowania pracy zarobkowej są obecnie wypłacane najuboższym świadczenia socjalne, zależne od progów dochodowości, ponieważ pułapki ubóstwa i prekarności czynią nieracjonalnym przejście od tych świadczeń do nisko płatnej i niepewnej pracy zarobkowej (Standing, 2015, s. 330).

Popularny jest też zarzut, że dochód podstawowy doprowadzi do wzrostu inflacji, ponieważ stymulowałby efektywny popyt, podnosząc ceny i tworząc oczekiwania inflacyjne. To zdaniem G. Standinga nie nastąi, bo dochód podstawowy zastąpiłby inne wydatki socjalne rządów. W dodatku w Japonii i w wielu krajach Europy od roku 2008 występuje deflacja i zwiększony efektywny popyt pobudziłby podaż dóbr i usług, ograniczając presję cenową. „Mielibyśmy również do czynienia z pozytywnymi skutkami wynikającymi ze skierowania efektywnego popytu na dobra podstawowe i usługi wytwarzane w lokalnych gospodarkach. Programy pilotażowe w Afryce i Indiach wykazały, że elastyczność podaży lokalnych dóbr i usług jest wysoka, efektem może więc być mniejsza presja inflacyjna" (Standing, 2015, s. 320-330).

Nie mają również podstaw zarzuty, że zwiększy się migracja do krajów wysokorozwiniętych, można przecież wprowadzić pragmatyczną zasadę, że uprawnienia byłyby przyznawane osobom legalnie przebywającym na terytorium danego kraju np. przez dwa lata, o ile nie doszło do wzajemnego porozumienia między krajem pochodzenia i legalnego zamieszkiwania (Standing, 2015, s. 331).

Niebezpieczeństwu „upolitycznienia dochodu podstawowego", polegające na kuszeniu rządów do podnoszenia jego wysokości przed wyborami, można zapobiec przez: „utworzenie niezależnej instytucji, analogicznie do banku centralnego, mającej mandat do ustalania poziomu dochodu podstawowego i sposobu jego zmian w odniesieniu do możliwości i potrzeb finansowych oraz wzrostu gospodarczego" (Standing, 2015, s. 331).

Najbardziej niepokoi negatywne stanowisko związków zawodowych wobec dochodu podstawowego. Warto przytoczyć dosłownie opinię G. Standinga w tej sprawie; „Tradycyjne związki zawodowe najżarliwiej sprzeciwiały się dochodowi podstawowemu. Broniły radykalnej redystrybucji dochodu, a jednak uparcie trzymały się laburystycznego myślenia, że jedynie tym, którzy wykonują pracę najemną, należy się dochód. Nowoczesny młody związkowiec może myśleć inaczej. Przemawiając podczas międzynarodowej związkowej szkoły letniej w 2012 roku, zapytałem, dlaczego związki zawodowe sprzeciwiają się dochodowi podstawowemu. Jeden Włoch odważył się powiedzieć, że dałoby to pracownikom więcej kontroli i nie chcieliby już przystępować do związków. Jak się zorientowałem, nie wystawił tym samym najlepszego świadectwa związkom. Powinny one przyciągać członków raczej przez walkę o prawa pracownicze i redystrybucję" (Standing, 2015, s. 332) Wbrew opinii związkowców posiadanie podstawowego bezpieczeństwa $\mathrm{w}$ postaci dochodu podstawowego zwiększa, a nie zmniej- 
sza prawdopodobieństwo zbiorowej społecznej aktywności. Dowodzi to równocześnie, że solidarność społeczna złożona w ofierze w erze globalizacji musi zostać odnowiona. Sam dochód podstawowy do tego na pewno nie doprowadzi, ale powinien być kluczowym czynnikiem odbudowy solidarności społecznej w dobie globalizacji.

Uznają to już behawioryści, bo - jak wykazały badania psychologów (Frohlich, Oppenheimer, 1993) - ludzie posiadający podstawowe bezpieczeństwo dochodu są bardziej skłonni do altruizmu i hojności, względem tych, którym w życie się nie poszczęściło. W tych samych badaniach wykazano też, że są oni bardziej wydajni w swojej pracy i bardziej tolerancyjni wobec obcych i innych, którzy mogliby być postrzegani jako konkurencja i zagrożenie (Standing, 2015, s. 333).

Dochód podstawowy niesie z sobą znaczącą poprawę stylu życia prekariusza poprzez efekt poprawy jego płynności finansowej. Połączenie niskich i niepewnych dochodów, które go dotyka, wpływa na zadłużenie, problemy ze spłatą kolejnej raty oraz niemożność planowania i samodzielnego budowania własnego życia. Regularna, gwarantowana dawka finansowej płynności może już zapewnić odrobinę kontroli nad własnym życiem. Potwierdziła to seria badań pilotażowych przeprowadzonych $\mathrm{w}$ Indiach $\mathrm{w}$ latach 2011-2013 (Standing, 2013). Efekt poprawy płynności wpływa korzystnie na poczucie wspólnoty. Bezwarunkowe powszechne transfery pieniężne umożliwiają rodzinom i sąsiadom zebranie pieniędzy na usprawnienia i pomoc tym, których dotknęła katastrofa. Kiedy jedna osoba we wspólnocie otrzymuje świadczenia, inni mogą o tym nie wiedzieć lub może prowadzić to do zazdrości czy zarzutów o niesprawiedliwość. W momencie gdy wszyscy otrzymują to samo świadczenie, nie tylko możliwe są zbiórki na cele społeczne czy ekonomiczne, lecz także wytwarza się pozytywna atmosfera moralnej presji. Zaobserwowano ją w badaniach programu pilotażowego w Namibii - kiedy dziecko nie chodziło do szkoły, sąsiedzi czuli się uprawnieni do pytania - dlaczego tak jest? (Standing, 2015, s. 333).

Najistotniejszym skutkiem podstawowego dochodu dla wspólnoty jest zdobycie przez nią potencjału do przekształcania siebie i otoczenia. Powołane wcześniej badania we wioskach indyjskich w latach 2011-2013 wykazały, że przekraczane zostały rozmaite ograniczenia różnych ludzi. „Wspólnota $\mathrm{z}$ podstawowym bezpieczeństwem dochodu staje się bardziej dynamiczna, pewna siebie, skłonna do inwestowania i ulepszania lokalnego otoczenia" (Standing, 2015, s. 334).

Wyniki licznych badań i programów pilotażowych powoływane przez G. Standinga potwierdzają też, że programy bezwarunkowe i powszechne przynoszą większe długoterminowe pozytywne skutki od świadczeń warunkowych skrojonych pod wybrane grupy. Pozwalają bowiem jednostkom i rodzinom lepiej i bardziej trwale rozwiązywać problemy, z którymi się na co dzień spotykają.

Ze względu na cel niniejszego artykułu najistotniejsza jest jednak ocena wpływu wprowadzenia instytucji bezwarunkowego, powszechnego dochodu podstawowego na bardziej efektywne i sprawiedliwsze funkcjonowanie współczesnych rynków pracy.
Fundamentem efektywnego funkcjonowania kapitalistycznej gospodarki rynkowej są wolne od wszelkiej władzy stosunki kontraktowe na rynkach towarów i usług, kapitału i pracy, zapewniające swobodne kształtowanie cen. W szczególności jakość transakcji na rynku pracy zależy od siły przetargowej oferującego pracę właściciela kapitału i pracobiorcy oferującego swoje usługi pracy. Przy wysokich stopach bezrobocia, luce w wykorzystaniu siły roboczej i niepewnym wsparciu dochodowym pozycja negocjacyjna pracownika jest wyjątkowo słaba. Pracownicy narażeni są na wyzysk, co obniża efektywność pracy najemnej, bowiem pracodawcy mogą z łatwością wypłacać niskie wynagrodzenia i osiągać $\mathrm{w}$ ten sposób nienależne zyski bez dbałości o właściwe i efektywne wykorzystanie siły roboczej. Pracownicy natomiast będą wystarczająco zdesperowani, aby podjąć się pierwszej lepszej pracy, aby otrzymać niezbędne do życia pieniądze i jednocześnie rozglądać się za czymś innym. Efektywność alokacyjna takiego rynku pracy będzie więc niska, rotacja kadr wysoka, a negatywne reakcje w miejscu pracy częste. Tak G. Standing charakteryzuje w skrócie obecne funkcjonowanie rynków pracy w gospodarce globalnej (Standing, 2015, s. 335).

Dochód podstawowy ułatwiłby pracownikom skuteczne poszukiwanie właściwego zatrudnienia, umożliwiając im dokonywanie bardziej przemyślanych wyborów i powodował większą presję na zatrudniających do efektywnego wykorzystania siły roboczej. Niezadowolenie częściej prowadziłoby do porzucenia nieodpowiadającej pracownikowi pracy. Jednocześnie silniejsze byłyby oddziaływanie motywujące do podejmowania poszukiwania pracy, bo bezwarunkowy dochód podstawowy wyeliminowałby pułapkę ubóstwa zniechęcającą do zajmowania nisko płatnych miejsc pracy ze względu na niebezpieczeństwo utraty otrzymywanej wcześniej warunkowej pomocy społecznej.

Zwiększona siła przetargowa pracowników wywarłaby nacisk na pracodawców do poprawiania wydajności i atrakcyjności miejsc pracy, wzmacniając nacisk na humanizację pracy najemnej, zgodnie z kierunkiem stosunków międzyludzkich (human relations) w teorii i praktyce zarządzania, który zrodził się jeszcze w latach 20 . XX wieku w wyniku słynnych badań pracy w zakładach Western Elektric Campany w Hawthorne na przedmieściach Chicago, przeprowadzonych pod kierunkiem Eltona Mayo - profesora psychologii z Harwardu.

Istotne są też skutki wprowadzenia bezwarunkowego powszechnego dochodu podstawowego z punktu widzenia rosnącej liczby osób zaliczanych do prekariatu. Progresywna część prekariatu zyskałaby nie tylko poczucie bezpieczeństwa, lecz także uzyskała więcej wolności do pracy zarobkowej i niezarobkowej, a także wypoczynku, zarówno w sensie twórczym, jak i reprodukcyjnym. Dochód podstawowy zwiększyłby poczucie wolności w czasie rosnącego wykorzystywania moralizującej warunkowości, ścisłego monitorowania osobistych zachowań, nadzoru i stałej inwigilacji danych cyfrowych. Wreszcie zmniejszyłby szczególnie dokuczliwą niepewność ekonomiczną związaną z ciągłym zaostrzaniem warunkowości.

Można więc $\mathrm{z}$ dużym prawdopodobieństwem powiedzieć, że stopniowe wprowadzanie w krajach wysoko- 
rozwiniętych powszechnego, bezwarunkowego dochodu podstawowego, powinno stanowić trwałą podstawę powrotu równowagi na rynki pracy w gospodarce globalnej. Konieczne są więc dalsze naukowe analizy możliwości wprowadzania instytucji powszechnego bezwarunkowego dochodu podstawowego w krajach wysokorozwiniętych, eksperymentalne uruchamianie kolejnych programów pilotażowych w różnych krajach świata i uparte dążenie do osiągnięcia masy krytycznej, warunkującej pierwsze wdrożenie koncepcji w jednym z krajów bogatych.

\section{Podsumowanie}

$\mathbf{P}$ rzeprowadzona dyskusja literatury światowej wskazuje jednoznacznie na konieczność intensywnych działań, zarówno w obszarach nauki, jak i praktyki gospodarczej, na rzecz wdrożenia instytucji dochodu podstawowego, który stanowiłby bazę trwałego powrotu równowagi między pracą a kapitałem na współczesnym, globalnym rynku pracy. Obecne dysfunkcje rynku pracy obniżają bowiem wyraźnie jego efektywność, hamują tempo rozwoju krajów rozwiniętych gospodarczo, prowadzą do marnotrawstwa najcenniejszej wartości, jaką jest praca ludzka i dehumanizują stosunki międzyludzkie.

Działania związane $\mathrm{z}$ procesem wdrażania dochodu podstawowego wnoszą jednak w każdym kraju określony poziom ryzyka i z tego względu muszą być prowadzone bardzo ostrożnie - na zasadach suwerennych decyzji społeczeństw narodowych. Istotne jest przy tym pełne wykorzystywanie dorobku podejścia behawioralnego w ekonomii, bo zasadniczą przeszkodą jest konflikt tej idei z dotychczasowymi poglądami i przyzwyczajeniami oraz wynikającymi z nich zachowaniami społecznymi.

Zagadnienia te szczególnie są istotne w naszym kraju ze względu na dominację postaw konserwatywnych i łatwości demagogicznego zniekształcania opinii społecznej. Przykładem jest szybkie rozprzestrzenianie się błędnej opinii, że wejście Polski do strefy euro winno nastąpić po „osiągnięciu poziomu życia w krajach zachodnich”. W rzeczywistości zaś pozostawanie poza strefą euro zwalnia tempo naszego rozwoju, i niesie olbrzymie ryzyko trwałej utraty dystansu do krajów strefy euro w przypadku ściślejszej integracji krajów tej strefy. W konsekwencji niepodejmowanie tematu przygotowania wejścia do strefy euro oddala możliwość rozpoczęcia dyskusji na temat wprowadzania dochodu podstawowego dla obywateli Polski ze względu na utrzymywanie naszego PKB na niskim poziomie. Powstaje też wysokie ryzyko, że ewentualne wprowadzenie dochodu podstawowego w którymkolwiek z bogatszych krajów Unii Europejskiej zdemoluje całkowicie nasz lokalny rynek pracy oraz podniesie, i tak bardzo już dla nas dokuczliwą, presję migracyjną.

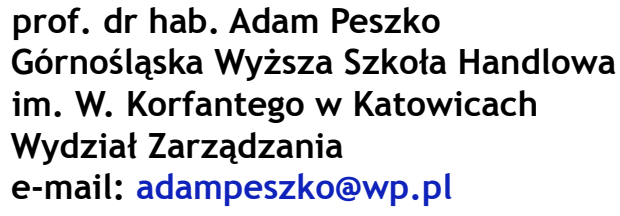

\section{Bibliografia}

[1] Ansoff H.I. (1985), Zarządzanie strategiczne, Państwowe Wydawnictwo Ekonomiczne, Warszawa.

[2] Frohlich N., Oppenheimer J.A. (1993), Choosing Justice. An Experimental Approach to Ethical Theory, University of California Press, Berkeley and Los Angeles.

[3] Kowanda C. (2017), 1000 euro dla każdego, rozmowa $z$ ekonomista prof. Thomasem Straubhaarem o tym, dlaczego dochód podstawowy to pomyst na wskroś liberalny, który wywoła rewolucje podatkowa, a nawet zastapi emerytury, „Polityka”, Nr 37, s. 36-38.

[4] Laska L. (2018), Co przyniesie nowy Kodeks pracy, „Przegląd”, Nr 5(943), s. 42.

[5] Peszko A. (2017), Społeczne aspekty wzrostu nierówności w liberalnej gospodarce globalnej, „Przegląd Organizacji", Nr 6, s. 50-56.

[6] Piketty T. (2015), Kapitał XXI wieku, Wydawnictwo Krytyki Politycznej, Warszawa.

[7] Radzikowski A. (2018), Fiasko nowego Kodeksu pracy? „Trybuna”, Nr 84-87, s. 5.

[8] Rozwadowska A. (2018), Co dalej z nowym prawem pracy? Kodeks innych intencji, "Gazeta Wyborcza” $\mathrm{z}$ dnia 28.03.2018.

[9] Standing G. (2015), Karta prekariatu, Wydawnictwo Naukowe PWN, Warszawa.

[10] Standing G. (2013), The Poor Are Responsible Too, „Financial Express", India, http://epaperfinancialexpress. com/, access date: 06.06.2013.

[11] Stiglitz J.E. (2015), Cena nierówności. W jaki sposób dzisiejsze podziały społeczne zagrażaja naszej przyszłości? Wydawnictwo Krytyki Politycznej, Warszawa.

[12] Williamson O.E. (1998), Ekonomiczne instytucje kapitalizmu. Firmy, rynki, relacje kontraktowe, Wydawnictwo Naukowe PWN, Warszawa.

[13] Woś R. (2017), Praca powraca, „Polityka”, Nr 17/18, s. 53.

[14] Woś R. (2018), Podzwonne na Święto Pracy, „Polityka” Nr $17 / 18$, s. 7.

\section{Universal and Unconditional Basic Income as a Real Factor in Rebalancing the Labor Markets}

\section{Summary}

The study presents the concept of Guy Standing's general and unconditional basic income. Based on the above concept, an analysis has been conducted, which concerns the possibility of returning to the labor markets in countries that will provide their citizens with the payment of such a basic income. The results of the aforementioned analysis are positive.

\section{Keywords}

global economy, labor market, general and unconditional income 